\title{
Presynaptic Calcium Channels in Rat Cortical Synaptosomes: Fast-Kinetics of Phasic Calcium Influx, Channel Inactivation, and Relationship to Nitrendipine Receptors
}

\author{
J. B. Suszkiw, ${ }^{\star}$ M. E. O’Leary, ${ }^{*}$ M. M. Murawsky, ${ }^{\star}$ and T. Wang $\dagger$ \\ *Departments of Physiology and Biophysics and †Pharmacology and Cell Biophysics, \\ University of Cincinnati College of Medicine, Cincinnati, Ohio 45267-0576
}

Fast-mixing and rapid-filtration techniques were used to analyze the kinetics of potassium-depolarization-dependent $\left(\Delta \mathrm{K}^{+}=\right.$ 47.5 $\mathrm{mM}$ ) influx of ${ }^{45} \mathrm{Ca}$ into synaptosomes, in the time range from 50 msec to $5 \mathrm{sec}$. The results are consistent with the presence in synaptosomes of a homogenous population of voltagesensitive Ca channels. With $1 \mathrm{mM} \mathrm{Ca}$ in the medium, the $\Delta \mathbf{K}^{+}-$ dependent $\mathrm{Ca}$ influx has a single-exponential time course with the half-life, $t_{1 / 2} \sim 0.5-0.7 \mathrm{sec}$. Ca influx, measured between 0.1 and $10 \mathrm{mM} \mathrm{Ca}_{0}$, shows half-saturation $\left(K_{\mathrm{Ca}_{\mathrm{a}}}\right)$ at $1.5 \mathrm{~mm} \mathrm{Ca}$ and has the limiting value $\left(J_{\mathrm{Ca}^{\text {max }}}\right)$ of $5.9 \mathrm{nmol} / \mathrm{sec} / \mathrm{mg}$ protein, or a current of approximately $0.06 \mathrm{pA} / \mu \mathrm{m}^{2}$ surface area. The estimated density of functional Ca channels is $0.6-6 \mu \mathrm{m}^{-2}$.

Voltage- and time-dependent inactivation of $\mathrm{Ca}$ channels was measured in synaptosomes predepolarized in $52.5 \mathrm{mM} \mathrm{K}_{\mathrm{o}}^{+}$with Ca omitted from the medium. Channel inactivation is a singleexponential process with a half-life of $t_{1 / 2} \sim 2.3 \mathrm{sec}$. Channel recovery in $5 \mathrm{mM} \mathrm{K}_{0}^{+}$media is likewise a single-exponential process with a half-life of $t_{1 / 2} \sim \mathbf{4 . 3} \mathrm{sec}$. The slower rate of voltage-dependent channel inactivation than of decay of $\mathrm{Ca}$ influx suggests that $\mathrm{Ca}$ entry into synaptosomes terminates by a mechanism that depends on $\mathrm{Ca}$ influx itself.

Synaptosomes contain $200 \mathrm{fmol} / \mathrm{mg}$ protein, or $\sim 6 \mu \mathrm{m}^{-2}$ highaffinity $\left(K_{\mathrm{D}}=0.12 \mathrm{nM}\right)^{3} \mathrm{H}$-nitrendipine binding sites; however, nitrendipine at concentrations $>10^{4} \times K_{\mathrm{D}}$ is without effect on the phasic influx of $C$ a measured at $215 \mathrm{msec}$ with either 1.0 or $0.1 \mathrm{mM} \mathrm{Ca}$. This suggests that $\mathrm{Ca}$ channels characterized in this study belong to a class of dihydropyridine-insensitive channels.

In view of the importance of voltage-gated $\mathrm{Ca}$ influx in the release of neurotransmitters (Katz, 1969; Llinás and Heuser, 1977), it is of considerable interest to characterize the biophysical and pharmacological properties of $\mathrm{Ca}$ channels in nerve terminals and elucidate the factors that regulate the functional state of the channels. Investigation of presynaptic voltage-sensitive $\mathrm{Ca}$ channels in brain has been hindered by the inaccessibility of presynaptic terminals to direct electrophysiological recording techniques; however, it is possible to characterize properties of these channels from measurements of $\mathrm{K}^{+}$-depolarization-dependent ${ }^{45} \mathrm{Ca}$ influx in isolated nerve terminals in vitro, i.e., synaptosomes.

In synaptosomes, the $\mathrm{K}^{+}$-depolarization-stimulated Ca entry is biphasic and consists of "fast" and "slow" components (Nachshen and Blaustein, 1980, 1982). There is evidence suggesting that the initial, rapidly decaying phase of $\mathrm{Ca}$ influx is associated with the opening and subsequent inactivation of Ca channels

Received July 18, 1985; revised Sept. 30, 1985; accepted Oct. 23, 1985.

This work was supported by National Institutes of Health Grant NS 20786.

Correspondence should be addressed to Dr. Suszkiw at the above address.

Copyright (C) 1986 Society for Neuroscience 0270-6474/86/051349-09\$02.00/0
(Nachshen, 1985; Nachshen and Blaustein, 1980, 1982) and that these channels mediate brisk, transient release of transmitters from synaptosomes (Drapeau and Blaustein, 1983; Suszkiw and O'Leary, 1983).

Inactivation and reactivation of $\mathrm{Ca}$ channels in nerve terminals is of considerable interest as a potential mechanism of transmitter-release modulation. Reversible voltage and/or $\mathrm{Ca}_{\mathrm{i}^{-}}$ dependent channel inactivation has been described in a number of different systems (for review, see Hagiwara and Byerly, 1981; Kostyuk, 1981; Tsien, 1983). Nachshen (1985) suggested that the rapid decay of $\mathrm{Ca}$ influx, measured in the millisecond range, reflects primarily a voltage-dependent inactivation of the synaptosomal Ca channels; however, it is not entirely clear if, and to what extent, $\mathrm{Ca}$ entry itself may contribute to the observed decay of $\mathrm{Ca}$ influx in synaptosomes. A Ca-dependent channel inactivation has been demonstrated in the squid giant axon terminals (Augustine and Eckert, 1984).

Several reports indicate that synaptosomal $\mathrm{Ca}$ channels are not sensitive to the myocardial and smooth muscle $\mathrm{Ca}$ channel antagonists such as nitrendipine and related dihydropyridines (Daniell et al., 1983; Nachshen and Blaustein, 1979; Rampe et al., 1984); however, this has recently been questioned (Turner and Goldin, 1985). Thus, although synaptosomes contain specific high-affinity receptors for nitrendipine and related dihydropyridines (Rampe et al., 1984; Yamamura et al., 1982), the relation of these receptors to the presynaptic $\mathrm{Ca}$ channels remains conjectural (Miller, 1985; Miller and Friedman, 1984).

In the present study we attempted (1) to characterize the kinetics of $\mathrm{Ca}$ channels in synaptosomes and estimate the density of functional channels from the $\mathrm{Ca}$ flux measurements in the millisecond time rangc, (2) to characterize the timc coursc of channels inactivation and recovery, and determine whether the decay of $\mathrm{Ca}$ influx in synaptosomes is associated with a voltage- or $\mathrm{Ca}_{\mathrm{i}}$-dependent channel inactivation, and (3) to compare the density of ${ }^{3} \mathrm{H}$-nitrendipine binding sites with the estimated number of functional Ca channels in synaptosomes, and examine the effect of nitrendipine on the initial rates of $\mathrm{K}^{+}$stimulated $\mathrm{Ca}$ influx in the millisecond time range. Preliminary accounts of this work have appeared in abstract form (O'Leary and Suszkiw, 1985; Wang et al., 1985).

\section{Materials and Methods}

\section{Materials}

${ }^{45} \mathrm{CaCl}_{2}$ (13-47 mCi/mg), 5-methyl- ${ }^{3} \mathrm{H}$-nitrendipine $(81.3 \mathrm{Ci} / \mathrm{mmol}$, lot no. $2175-088),{ }^{14} \mathrm{C}(\mathrm{U})$-sucrose $\left(273 \mathrm{mCi} / \mathrm{mm}\right.$ ), and ${ }^{3} \mathrm{H}_{2} \mathrm{O}(25 \mathrm{mCi} /$ $\mathrm{gm})$, were obtained from New England Nuclear (Boston). Nitrendipine was obtained from Miles Laboratories, Inc. (New Haven, NJ). TTX, quin-2, and its acetoxymethyl tetraester, quin-2AM, were obtained from Sigma Chemical Co. (St. Louis). All other chemicals were of reagent grade. 


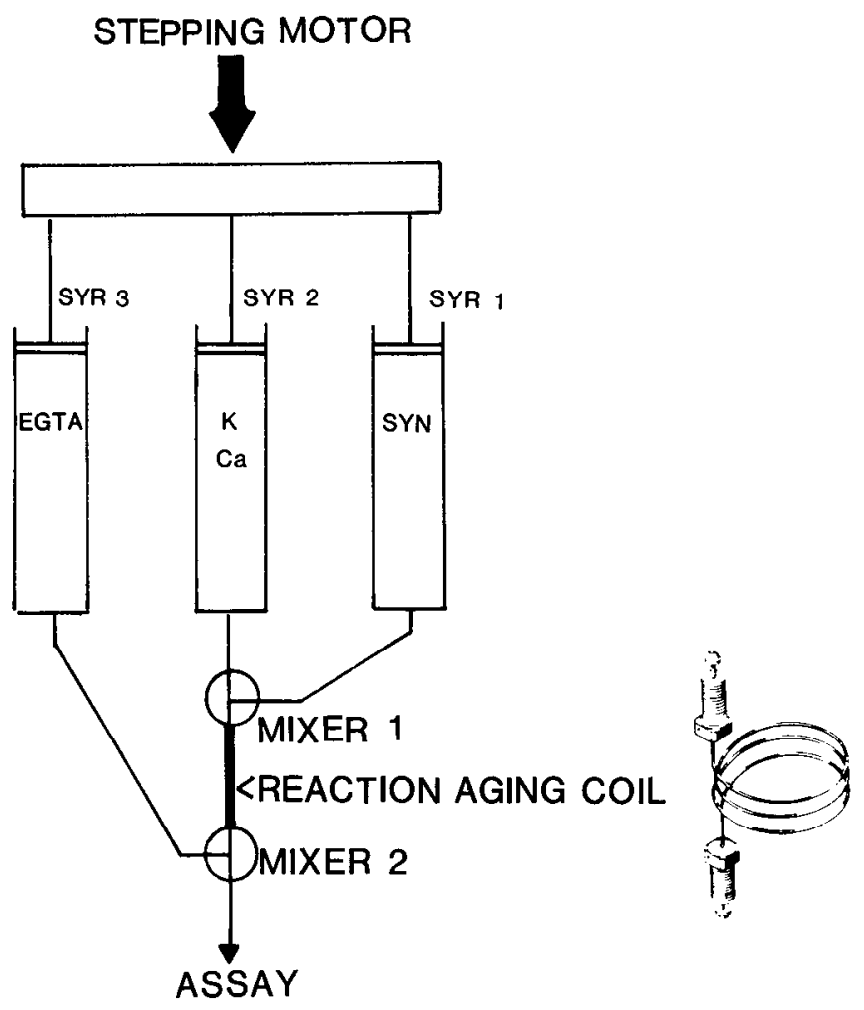

Figure 1. Schematic of quench-flow (QF) procedure. Syringe (Syr I) suspension of synaptosomes in HKR; Syr 2, low- or high-K ${ }^{+}-\mathrm{HKR}$ and ${ }^{45} \mathrm{Ca}$; Syr 3, $30 \mathrm{~mm}$ EGTA-quench solution. Activation of stepping motor drives syringe pistons and initiates the flow and mixing of solutions in 1:1:1 volume ratios at precisely controlled times. Berger ball mixers provide rapid mixing and allow measurements of reaction rates with half-lives of less than $5 \mathrm{msec}$. The uptake time is determined by the transit time of reaction medium through the aging coil. Qucnched reaction medium is collected in a test tube and synaptosomes are immediately separated from the medium by filtration. For detailed description of QF apparatus, see Froehlich et al. (1976).

\section{Media}

Standard suspension medium was a HEPES-buffered Krebs-Ringer (HKR) solution composed of $140 \mathrm{~mm} \mathrm{NaCl}, 5 \mathrm{~mm} \mathrm{KCl}, 1.3 \mathrm{~mm} \mathrm{MgCl}$, $10 \mathrm{~mm}$ glucose, and $5 \mathrm{~mm}$ Na-HEPES, $\mathrm{pH} \mathrm{7.4}$. $\mathrm{Na}^{+}$-deficient solutions were made by isosmotic substitution of $\mathrm{NaCl}$ by choline chloride (ChHKR). The depolarizing media were made by isosmotically substituting $\mathrm{KCl}$ for $\mathrm{NaCl}$ (or for $\mathrm{ChCl}$ in Na-deficient media), in proportions such as to yield after mixing with synaptosomes, $52.5 \mathrm{mM} \mathrm{K}^{+}$and $92.5 \mathrm{~mm}$ $\mathrm{Na}^{+}$in the case of $\mathrm{Na}^{+}$-containing media, and $52.5 \mathrm{mM} \mathrm{K}+$ and 92.5 $\mathrm{mm} \mathrm{Ch}{ }^{+}$in the case of $\mathrm{Na}^{+}$-deficient media. The nondepolarizing, low $\mathrm{K}^{+}-\mathrm{HKR}$ media were modified by substituting equivalent concentrations of $\mathrm{LiCl}$ or $\mathrm{ChCl}$ for $\mathrm{NaCl}$ so that after mixing with synaptosomes the final concentrations in the basal conditions were $5 \mathrm{mM} \mathrm{K}^{+}, 92.5$ mм Na${ }^{+}$, and $47.5 \mathrm{mM} \mathrm{Ch}^{+}$or $\mathrm{Li}^{+}$. In the case of nondepolarizing, $\mathrm{Na}^{+}$-deficient solutions, either $\mathrm{LiCl}$ substitution was used to obtain 5 $\mathrm{mm} \mathrm{K} \mathrm{K}^{+}, 92.5 \mathrm{mM} \mathrm{Ch}^{+}$, and $47.5 \mathrm{mM} \mathrm{Li}^{+}$, or Ch-HKR was used directly without further modifications. EGTA-quench solutions were made in HKR or Ch-HKR. Depending on the procedure, these solutions contained either 20 or $30 \mathrm{~mm}$ EGTA, with $\mathrm{NaCl}$ or $\mathrm{ChCl}$ appropriately reduced to maintain isosmolarity. The EGTA-wash solutions contained $1 \mathrm{~mm}$ EGTA in standard HKR. All solutions were oxygenated prior to experiments and maintained at $\mathrm{pH}$ 7.4.

\section{Preparation of synaptosomes}

Synaptosomes were isolated from cerebral cortices of Sprague-Dawley rats (175-200 gm body weight) by the method of Gray and Whittaker (1962) as described by us previously (Suszkiw and O'Leary, 1983). After purification in sucrose density gradients, synaptosomes were slowly diluted with 10 vol of HKR or Ch-HKR solutions, pelleted at $10,000 \times$ $g$ for $20 \mathrm{~min}$ and resuspended in the respective medium. All preparative steps were performed at $4^{\circ} \mathrm{C}$. All subsequent measurements were done at $30^{\circ} \mathrm{C}$ after preincubating synaptosomes at this temperature for $10-$ $20 \mathrm{~min}$. Synaptosomal protein was determined by the procedure of Lowry et al. (1951) with crystalline bovine albumin as the standard.

\section{Measurements of ${ }^{45} \mathrm{Ca}$ uptake}

A Froehlich-Berger Chemical Quench Flow (QF) apparatus (Commonwealth Technologies Inc., VA) was used for measurements of ${ }^{45} \mathrm{Ca}$ uptake between 0.05 and $1 \mathrm{sec}$ reaction time. In this procedure (Fig. 1), uptake reaction was initiated by mixing synaptosomes (syringe 1) with high- or low- $\mathrm{K}^{+}$medium, which contained various concentrations of $\mathrm{CaCl}_{2}$ and ${ }^{45} \mathrm{Ca}$ tracer (syringe 2). After variable reaction times, determined by the transit time through the "aging coil," uptake was terminated with $30 \mathrm{~mm}$ EGTA-quench solution (10 mM EGTA after mixing; delivered from syringe 3 ). Aliquots $(0.8 \mathrm{ml})$ of the quenched samples were rapidly filtered through $0.65 \mu \mathrm{m}$ Millipore (type DAWP 025) filters held under suction in a Swinex filter holder modified to allow easy access to the filter. The filters were rapidly rinsed $3 \times$ each with $5 \mathrm{ml}$ of EGIAwash solution, air-dried, and placed in scintillation vials containing 1 $\mathrm{ml}$ of $1 \%$ Triton X-100 in $0.1 \mathrm{~N} \mathrm{HCl}$. After about 20 min elution, 10 $\mathrm{ml}$ of scintillation fluor in toluene-Triton X-100 [2:1, vol/vol; $4 \mathrm{gm} 2.5-$ diphenyloxazole, and $0.05 \mathrm{gm} \mathrm{1,4-bis-(5-phenyloxazolyl)}$ benzene/Ltoluene] was added, and the radioactivity was measured in a Beckman LS9000 scintillation spectrometer in the quench correction mode. In a typical experiment, 14-16 measurements could be obtained with synaptosomes prepared from three rat brains. The concentration of synaptosome protein employed was about $1 \mathrm{mg} / \mathrm{ml}$ of suspension. Depending on the total concentration of $\mathrm{Ca}, 1-10 \mu \mathrm{Ci}{ }^{45} \mathrm{Ca}$ tracer $/ \mathrm{ml}$ of reaction medium was used.

Manual procedure was used in the measurements at times $1 \mathrm{sec}$ or longer. In this procedure, $450 \mu \mathrm{l}$ of either low- or high-K-HKR medium, containing the desired concentration of $\mathrm{CaCl}_{2}$ and ${ }^{4} \mathrm{Ca}$ tracer $(1-10 \mu \mathrm{Ci}$ ) $\mathrm{ml}$ ) was rapidly injected into a test tube containing $50 \mu \mathrm{l}$ of synaptosome suspension $(0.2-0.5 \mathrm{mg}$ protein), and after various time intervals the uptake reaction was stopped by injecting $0.5 \mathrm{ml}$ of $20 \mathrm{~mm}$ EGTA-quench solution. Aliquots $(0.8 \mathrm{ml})$ of the samples were immediately filtered, and the filters were processed exactly as described for the QF experiments. The concentrations of $\mathrm{Na}^{+}$and $\mathrm{K}^{+}$in low- and high- $\mathrm{K}^{+}$media were adjusted to provide after mixing with synaptosomes exactly the same ionic composition as in QF experiments. The injections of media were timed with electronic timer calibrated in $1 / 100$ th sec divisions (A.W. Haydon Co.) and were made with $1 \mathrm{ml}$ tuberculin syringes fitted with $7.5 \mathrm{~cm}$ long, 20 gauge stainless steel needles. The needles were secured to stoppers in $15 \times 100 \mathrm{~mm}$ polystyrene test tubes. A rapid depression of syringe plunger delivered a jet of liquid causing a turbulent mixing of the reaction media. We have confirmed that this manual method for measuring $\mathrm{Ca}$ uptake yielded results that were comparable to within $10 \%$ of those obtained by the quench-flow procedure.

Net $\Delta K^{+}$-stimulated influx of Ca was calculated after subtracting ${ }^{45} \mathrm{Ca}$ uptake by synaptosomes in $5 \mathrm{~mm} \mathrm{~K}^{+}$from uptake in $52.5 \mathrm{~mm} \mathrm{~K}^{+}$. The results were expressed as $\mathrm{nmol} \mathrm{Ca} / \mathrm{mg}$ protein, on the basis of specific radioactivity of ${ }^{45} \mathrm{Ca}$ in the medium.

\section{Time course of $\mathrm{Ca}$ channel inactivation and recovery from inactivation}

Synaptosomes were "predepolarized" by mixing $50 \mu$ l of synaptosome suspension with $450 \mu \mathrm{l}$ of high K-HKR as described for uptake experiments, except that in this case Ca was omitted from the high- $\mathrm{K}^{+}$medium. After $1-30 \mathrm{sec}$ of predepolarization, $1 \mathrm{ml}$ of $52.5 \mathrm{~mm} \mathrm{~K}-\mathrm{HKR}$ containing ${ }^{45} \mathrm{Ca}$ was injected into the reaction medium to initiate the uptake reaction. Uptake was terminated after $1 \mathrm{sec}$ by quenching the reaction with $1.5 \mathrm{ml}$ of $20 \mathrm{~mm}$ EGTA-quench solution. Aliquots of quenched samples were immediately filtered and processed as described in Ca uptake experiments. Reactivation of the channels was measured as follows. In order to inactivate Ca channels, synaptosomes were first predepolarized for $10 \mathrm{sec}$ in $52.5 \mathrm{~mm}$ K-HKR by mixing $25 \mu$ laliquots of synaptosomes with $25 \mu \mathrm{l}$ of $100 \mathrm{~mm} \mathrm{~K}$-HKR solution. At the end of predepolarization, the mixture was rapidly diluted 10.5 -fold by injecting $475 \mu \mathrm{l}$ of appropriately modified $\mathrm{K}^{+}$-free $\mathrm{HKR}$ to reduce $\mathrm{K}^{+}$concentration back to $5 \mathrm{~mm}$, without otherwise altering the composition of the

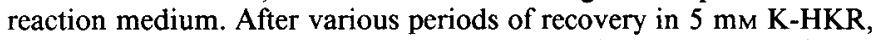
the channel activity was assayed by injecting into the suspension 1 $\mathrm{ml}$ of high-K-HKR- ${ }^{45} \mathrm{Ca}$ medium, so that after mixing, the concentration of $\mathrm{K}^{+}$was restored to $52.5 \mathrm{~mm}$ and the concentrations of other 
ions remained unchanged. After $1 \mathrm{sec}$ incubation, uptake of ${ }^{45} \mathrm{Ca}$ was stopped by injecting $1.5 \mathrm{ml}$ of $20 \mathrm{~mm}$ EGTA-quench solution. Aliquots of quenched reaction mixing were rapidly filtered through the Millipore filters, which were then handled in the usual way. The background uptake was measured in parallel by exposing synaptosomes to low ( 5 $\mathrm{mm} \mathrm{K} \mathrm{K}^{+}$) solutions in place of $52.5 \mathrm{~mm} \mathrm{~K}^{+}$. After subtracting the background uptake, the $\Delta \mathrm{K}^{+}$-dependent ${ }^{45} \mathrm{Ca}$ uptake was expressed as a fraction of the control uptake in synaptosomes at zero-time of the predepolarization-repolarization sequence.

\section{Equilibrium binding of ${ }^{3} \mathrm{H}$-nitrendipine}

Equilibrium binding of ${ }^{3} \mathrm{H}$-nitrendipine (NTD) was performed essentially as described by Rampe et al. (1984). Synaptosomes (approx. 200$400 \mu \mathrm{g}$ protein) were incubated $60 \mathrm{~min}$ at $4^{\circ} \mathrm{C}$ in $5 \mathrm{ml} \mathrm{Ch}-\mathrm{HKR}$ containing $0.02-1.5 \mathrm{~nm}{ }^{3} \mathrm{H}-\mathrm{NTD}$. Nonspecific binding was assayed in parallel, in the presence of excess $(1 \mu \mathrm{M})$ unlabeled NTD. The drug was made in absolute ethanol, and the final concentration of ethanol in the incubation mixtures was $0.1 \%$. All manipulations were done under darkroom (dim yellow light) conditions; the incubations were carried out in total darkness. After incubation, $4.5 \mathrm{ml}$ aliquots of suspensions were filtered through fiberglass, Whatman GF/F filters under gentle suction. The filters were washed with $15 \mathrm{ml}(3 \times 5 \mathrm{ml})$ of cold Ch-HKR and counted in toluene-Triton X-100 fluor as described for Ca uptake experiments. The remaining $0.5 \mathrm{ml}$ portions of the incubation media were centrifuged $20 \mathrm{sec}$ at $12,000 \times \mathrm{g}$ in a Fisher microfuge, and aliquots of the supernatants were counted to determine the equilibrium concentrations of free ${ }^{3} \mathrm{H}-\mathrm{NTD}$ in the media.

To determine effects of NTD on $\Delta \mathrm{K}^{+}$-stimulated Ca entry, synaptosomes were preincubated at $0-4^{\circ} \mathrm{C}$ for $60 \mathrm{~min}$ with a total of $10 \mu \mathrm{M}$ nitrendipine added, exactly as described for the equilibrium binding experiments. Control preparations were processed identically and contained $0.1 \%$ ethanol vehicle. After $60 \mathrm{~min}$ equilibration, synaptosomes were prewarmed for $10-20 \mathrm{~min}$ at $30^{\circ} \mathrm{C}$, and ${ }^{45} \mathrm{Ca}$ uptake was measured by means of the quench-flow apparatus.

\section{Determination of $\mathrm{Na}^{+}$and $\mathrm{K}^{+}$}

The $\mathrm{Na}^{+}$and $\mathrm{K}^{+}$content of synaptosomes was determined in a PerkinElmer 3030 Atomic Absorption Spectrophotometer. Aliquots $(250 \mu \mathrm{l}$, approx. $1 \mathrm{mg}$ protein) of synaptosome suspensions preequilibrated in HKR or Ch-HKR were filtered through $0.65 \mu \mathrm{m}$ Millipore filters. The filters were washed with $25 \mathrm{ml}$ of $\mathrm{Na}^{+}-$and $\mathrm{K}^{+}$-free, isosmotic ChHKR buffered with $10 \mathrm{~mm}$ HEPES-Tris, pH 7.4. After air-drying, the filters were extracted with $1 \mathrm{ml}$ of $0.1 \mathrm{~N} \mathrm{HCl}$, and aliquots of the extracts were assayed for $\mathrm{Na}^{+}$and $\mathrm{K}^{+}$against standard solutions of $\mathrm{NaCl}$ and $\mathrm{KCl}$ in $0.1 \mathrm{~N} \mathrm{HCl}$. Filter blanks were subtracted from the readings.

\section{Determination of intrasynaptosomal water space}

Suspensions of synaptosomes in HKR or Ch-HKR (200 $\mu$ l, approx. 0.4 mg protein) were incubated with approximately $0.4 \mu \mathrm{Ci}^{3} \mathrm{H}_{2} \mathrm{O}$ and 0.1 $\mu \mathrm{Ci}$ of ${ }^{14} \mathrm{C}(\mathrm{U})$ sucrose. After a $10-30$ min equilibration, synaptosomes were pelleted for $2 \mathrm{~min}$ at $12,000 \times g$ in a Fisher microfuge. The pellets were separated from the supernatants and lysed overnight in $0.5 \mathrm{ml}$ of $1 \%$ Triton X-100/0.1 N HCl. The ${ }^{3} \mathrm{H}$ and ${ }^{14} \mathrm{C}$ counts in the pellets and supernatants were measured in Beckman LS 9000 scintillation spectrometer optimized for double-label counting. The water space of synaptosomes was calculated after subtracting the ${ }^{3} \mathrm{H}_{2} \mathrm{O}$ associated with the ${ }^{14} \mathrm{C}$ sucrose space from total ${ }^{3} \mathrm{H}_{2} \mathrm{O}$ counts in the pellets.

\section{Determinations of free $\mathrm{Ca}_{i}$ with fluorescent calcium} indicator Quin 2

The procedure was based on the method of Tsien et al. (1982) essentially as described for synaptosomes by Ashley et al. (1984).

\section{Data analysis}

A nonlinear least-squares regression program BMDP P3R (Jennrich, 1983) was used for curve fitting.

\section{Results}

Synaptosomes have a number of Ca permeability pathways that could interfere with the measurement of $\mathrm{Ca}$ flux through the specific $\mathrm{Ca}$ channels. The influx of $\mathrm{Ca}$ through voltage-sensitive $\mathrm{Na}$ channels in $\mathrm{K}^{+}$-depolarized synaptosomes can be excluded, since these channels inactivate in a matter of a few milliseconds and we have confirmed that TTX $(1 \mu \mathrm{g} / \mathrm{ml})$ was without effect on the measured influx of ${ }^{45} \mathrm{Ca}$ (Nachshen and Blaustein, 1980). More problematic is the entry of $\mathrm{Ca}$ via the $\mathrm{Na} / \mathrm{Ca}$ exchange carrier. Since synaptosomes tend to accumulate significant amounts of $\mathrm{Na}^{+}$(Campbell, 1976; Coutinho et al., 1984; Marchbanks and Campbell, 1976), this may lead to the reversal of the $\mathrm{Na} / \mathrm{Ca}$ exchange that normally serves to extrude $\mathrm{Ca}$ from nerve terminals (Blaustein and Oborn, 1975; Mullins, 1976). Additional factors that must be considered in connection with high internal $\mathrm{Na}^{+}$in synaptosomes are the likelihood of partial depolarization of synaptosomes and increase in steady-state concentrations of free $\mathrm{Ca}_{i}$ in synaptoplasm due to enhanced entry of $\mathrm{Ca}$ from outside, as well as displacement of $\mathrm{Ca}$ from the intraterminal mitochondria (Carafoli and Crompton, 1978). Since inactivation of $\mathrm{Ca}$ channels may have both voltage- and $\mathrm{Ca}_{\mathrm{i}}$-dependent components, partial depolarization and elevation in $\mathrm{Ca}_{\mathrm{i}}$ may lead to progressive inactivation of channels in synaptosomes.

In order to assess the potential complications arising from accumulation of $\mathrm{Na}^{+}$in synaptosomes, we measured cation distribution in synaptosomes. Also, in some experiments we employed synaptosomes with low internal $\mathrm{Na}^{+}$concentration, obtained by suspending them in $\mathrm{Na}^{+}$-deficient $\mathrm{Ch}-\mathrm{HKR}$. Furthermore, to prevent unpredictable alterations in the levels of free $\mathrm{Ca}_{\mathrm{i}}$ in synaptosomes, we elected to omit $\mathrm{Ca}$ from the preincubation media. Finally, to minimize time-dependent variables among preparations, we routinely carried out all experiments within 45-60 min after suspension of synaptosomes in salt solutions and limited preincubations to $10-20 \mathrm{~min}$.

Concentrations of intrasynaptosomal $\mathrm{Na}^{+}, \mathrm{K}^{+}$, and $\mathrm{Ca}^{2+}$ in $\mathrm{Na}^{+}$-loaded and $\mathrm{Na}^{+}$-deficient preparations

Table 1 compares the concentrations of $\mathrm{Na}^{+}$and $\mathrm{K}^{+}$ions in synaptosomes suspended in standard, $\mathrm{Na}^{+}$-rich media (Na-syn) and in $\mathrm{Na}^{+}$-deficient, choline media (Ch-syn). The indicated redistribution of ions in synaptosomes apparently occurred during transfer of synaptosomes from sucrose to saline media at $0^{\circ} \mathrm{C}$. There was relatively small additional change in $\mathrm{Na}^{+}$and $\mathrm{K}^{+}$contents during subsequent $30 \mathrm{~min}$ incubation at $30^{\circ} \mathrm{C}$, indicating that at least with respect to $\mathrm{Na}^{+}$and $\mathrm{K}^{+}$distribution, synaptosomes were in steady state during this period of time. Essentially, all $\mathrm{Na}^{+}$and $\mathrm{K}^{+}$were associated with the osmotically sensitive compartment in synaptosomes, as osmotic lysis of synaptosomes resulted in readings that were cqual to the background levels of $\mathrm{Na}^{+}$and $\mathrm{K}^{+}$obtained from filters alone.

Synaptosomes in electron micrographs consist of morphologically intact nerve ending particles and vesiculated membranes devoid of cytoplasmic matrix and organelles. We have estimated in electron micrographs of our preparations the mean volume fraction of nerve endings and empty vesicles at about 80 and $20 \%$, respectively. The intrasynaptosomal water spaces measured with ${ }^{3} \mathrm{H}_{2} \mathrm{O}$ were $3.4 \pm 0.4 \mu \mathrm{l} / \mathrm{mg}$ protein in Na-syn and $3.0 \pm 0.4 \mu \mathrm{l} / \mathrm{mg}$ protein in Ch-syn (means $\pm \mathrm{SD}, n=6$ ), which after correction for the volume fraction of empty vesicles gives 2.7 and $2.4 \mu \mathrm{l} / \mathrm{mg}$ for the volume of morphologically intact synaptosomes in the respective preparations. With the simplifying assumptions that empty vesicles are metabolically inert and passively equilibrate with $\mathrm{Na}^{+}, \mathrm{K}^{+}$, and $\mathrm{Cl}^{-}$in the medium, and that synaptosomes can be treated as an "averaged" single compartment, we calculated the intrasynaptosomal concentrations of $\mathrm{Na}^{+}$and $\mathrm{K}^{+}$ions according to

$$
\left[X_{\mathrm{i}}\right]_{\mathrm{syn}}=\left(X_{\mathrm{T}}-\left[X_{\mathrm{o}}\right] V_{\mathrm{v}}\right) / V_{\mathrm{syn}}
$$

where $X$ is either $\mathrm{Na}^{+}$or $\mathrm{K}^{+},\left[X_{\mathrm{v}}\right]$ and $\left[X_{\mathrm{i}}\right]$ are molar concentrations of ion $X$ in the medium and synaptosomes, respectively, $V_{\mathrm{v}}$ is the volume of inert vesicles $(0.7$ and $0.6 \mu \mathrm{l} / \mathrm{mg}$ protein in Na-syn and Ch-syn preparations, respectively), and $V_{\text {syn }}$ is the volume of nerve ending particles $(2.7$ and $2.4 \mu \mathrm{l} / \mathrm{mg}$ protein for 


\begin{tabular}{|c|c|c|c|c|c|}
\hline \multirow{2}{*}{$\begin{array}{l}\text { Incuba- } \\
\text { tion } \\
\text { (min) }\end{array}$} & \multicolumn{2}{|c|}{ Content ( $\mu \mathrm{mol} / \mathrm{mg}$ protein) } & \multicolumn{2}{|c|}{ Concentration (mM) } & \multirow{2}{*}{$\begin{array}{l}\text { Membra } \\
\text { potential } \\
(\mathrm{mV})\end{array}$} \\
\hline & $\mathrm{Na}^{+}$ & $\mathrm{K}^{+}$ & $\mathrm{Na}^{+}$ & $\mathrm{K}^{+}$ & \\
\hline \multicolumn{6}{|l|}{ Na-syn } \\
\hline 0 & $0.309 \pm 0.075$ & $0.209 \pm 0.058$ & $77 \pm 20$ & $77 \pm 21$ & - \\
\hline 10 & $0.332 \pm 0.030$ & $0.223 \pm 0.025$ & $85 \pm 8$ & $83 \pm 9$ & -51 \\
\hline 20 & $0.369 \pm 0.048$ & $0.234 \pm 0.028$ & $99 \pm 13$ & $87 \pm 10$ & -52 \\
\hline 30 & $0.382 \pm 0.088$ & $0.232 \pm 0.038$ & $104 \pm 24$ & $86 \pm 14$ & -52 \\
\hline \multicolumn{6}{|l|}{ Ch-syn } \\
\hline 0 & $0.014 \pm 0.008$ & $0.293 \pm 0.054$ & $6 \pm 3$ & $122 \pm 22$ & - \\
\hline 10 & $0.010 \pm 0.003$ & $0.287 \pm 0.064$ & $4 \pm 1$ & $120 \pm 27$ & -83 \\
\hline 20 & $0.014 \pm 0.005$ & $0.263 \pm 0.045$ & $6 \pm 2$ & $109 \pm 19$ & -80 \\
\hline 30 & $0.013 \pm 0.006$ & $0.236 \pm 0.036$ & $5 \pm 2$ & $98 \pm 15$ & -78 \\
\hline
\end{tabular}

Incubations were at $30^{\circ} \mathrm{C}$; zero time: synaptosomes at $4^{\circ} \mathrm{C}$. The results are means $\pm \mathrm{SD} ; n=4$. Cation concentrations were calculated on basis of intrasynaptosomal ${ }^{3} \mathrm{H}_{2} \mathrm{O}$ spaces, corrected for volume fraction of contaminating structures (see text for details). Membrane potential was estimated according to the constant-field equation with the $\mathrm{Cl}^{-}$term omitted.

Na-syn and Ch-syn, respectively). The membrane potentials were estimated from the reduced constant-field equation:

$$
V_{\mathrm{m}, 30^{\circ}}=60 \mathrm{mV} \log \frac{P_{\mathrm{Na}} / P_{\mathrm{K}}[\mathrm{Na}]_{\mathrm{o}}+[\mathrm{K}]_{\mathrm{o}}}{P_{\mathrm{Na}} / P_{\mathrm{K}}[\mathrm{Na}]_{\mathrm{i}}+[\mathrm{K}]_{\mathrm{i}}}
$$

with $P_{\mathrm{Na}} / P_{\mathrm{K}}=0.05$ (Blaustein and Goldring, 1975; Keen and White, 1971).

The gain of $\mathrm{Na}^{+}$suggests a deficient $\mathrm{Na}, \mathrm{K}$-ATPase-driven extrusion of this ion and, by extension, an impairment of metabolic function of isolated nerve endings. It is likely that isolated nerve endings may exhibit a range of metabolic states, internal ionic concentrations, and resting membrane potentials. Thus, the assumption of a single "average" compartment used in the foregoing calculations may be questioned. Nevertheless, it may be concluded that on the average, synaptosomes equilibrated in standard Na-rich media are Na-loaded and may be depolarized by some $30 \mathrm{mV}$ relative to $\mathrm{Na}$-deficient synaptosomes equilibrated in choline media.

The measurements of free $\mathrm{Ca}_{\mathrm{i}}$ with Quin-2 incorporated into synaptosomes indicated low concentrations of ionized $\mathrm{Ca}_{\mathrm{i}}$ in both types of preparations. In the absence of $\mathrm{Ca}^{2+}$ in the suspension media, the mean $( \pm S D)$ concentrations of $\mathrm{Ca}_{\mathbf{i}}$ determined in six preparations were $28.2 \pm 8.7 \mathrm{nM}$ in synaptosomes suspended in HKR and $32.4 \pm 4.0 \mathrm{nM}$ in synaptosomes in ChHKR. Addition of $1 \mathrm{~mm} \mathrm{Ca}^{2+}$ to the media, resulted in a new steady-state concentration of $\mathrm{Ca}_{\mathrm{i}}$ of $77.8 \pm 16.7 \mathrm{nM}$ in Na-syn and $71.4 \pm 18.4 \mathrm{~nm}$ in Ch-syn. These values are similar to $104 \pm 8$ and $87.5 \pm 10 \mathrm{nM} \mathrm{Ca}_{\mathrm{i}}$ reported by Richards et al. (1984) and Ashley et al. (1984), respectively.

The maintenance of low $\mathrm{Ca}_{\mathrm{i}}$ in Na-loaded synaptosomes may be surprising at first. However, in $140 \mathrm{mM} \mathrm{Na}_{\circ}^{+}$, the estimated $\left[\mathrm{Na}_{i}^{+}\right]$in synaptosomes is $\sim 80-100 \mathrm{~mm}$ (Table 1 ), so under these conditions extrusion of $\mathrm{Ca}$ via $\mathrm{Na} / \mathrm{Ca}$ carrier may be still operative. On the other hand, lowering $\mathrm{Na}_{\mathrm{o}}^{+}$about $90 \mathrm{~mm}$ or less by substituting external $\mathrm{Na}^{+}$with $\mathrm{Li}^{+}$or $\mathrm{Ch}^{+}$leads to an increase in steady-state concentrations of $\mathrm{Ca}_{\mathrm{i}}$ in $\mathrm{Na}$-syn, and this effect is magnified in the presence of metabolic inhibitors (Ashley et al., 1984; J. B. Suszkiw, unpublished observations). In conclusion, assuming that Quin-2 monitors, rather than sets, free $\mathrm{Ca}_{\mathrm{i}}$ concentrations, these measurements suggest that both $\mathrm{Ch}$ - and $\mathrm{Na}$-syn are competent in maintaining the steady-state ionized $\mathrm{Ca}_{\mathrm{i}}$ at the submicromolar concentrations.

\section{Influx of $\mathrm{Ca}$ as a function of time}

These experiments compared ${ }^{45} \mathrm{Ca}$ influx in Na-syn and Ch-syn between 0.05 and $5 \mathrm{sec}$ of incubation in low $\mathrm{K}^{+}(5 \mathrm{~mm})$ and high $\mathrm{K}^{+}(52.5 \mathrm{~mm})$ media with $\mathrm{Ca}_{\mathrm{o}}=1 \mathrm{~mm}$ (Fig. 2). The basal rate of Ca uptake was $0.21 \mathrm{nmol} / \mathrm{sec} / \mathrm{mg}$ protein in Na-syn and $0.05 \mathrm{nmol} / \mathrm{sec} / \mathrm{mg}$ protein in Ch-syn. The higher rate of $\mathrm{Ca}$ uptake in $\mathrm{Na}^{+}$-loaded synaptosomes in conditions of lowered $\mathrm{Na}_{0}^{+}(92.5 \mathrm{nM})$ is consistent with "reversed" $\mathrm{Na} / \mathrm{Ca}$ exchange, which is inoperative in $\mathrm{Na}^{+}$-deficient $\mathrm{Ch}$-syn. Depolarization of synaptosomes in $52.5 \mathrm{~mm} \mathrm{~K}^{+}$resulted in a large, transient augmentation of $\mathrm{Ca}$ uptake. In $\mathrm{Ch}$-syn this initial increase in the rate of $\mathrm{Ca}$ influx subsided to nearly basal rate after about $1 \mathrm{sec}$ of $\mathrm{K}^{+}$depolarization, but in Na-syn the uptake remained somewhat enhanced relative to the basal rate. After subtracting the basal from the $\mathrm{K}^{+}$-stimulated $\mathrm{Ca}$ uptake, net $\Delta \mathrm{K}^{+}$-dependent influx of Ca was obtained (Fig. 3). In the case of Ch-syn, $\Delta \mathrm{K}^{+}-$ dependent influx of $\mathrm{Ca}$ followed a single-exponential time course and was fitted to the function $j=P\left(1-e^{-k t}\right)$, where $j$ is the $\mathrm{Ca}^{2+}$ influx measured at times $t, P$ is the plateau value of $\mathrm{Ca}$ cumulation, and $k$ is the observed first-order rate constant. Nonlinear least-squares regression of the data gave $k=1.3 \pm 0.1 \mathrm{sec}^{-1}$ and $P=3.02 \pm 0.15 \mathrm{nmol} / \mathrm{mg}$ protein. In contrast, $\mathrm{Ca}$ influx in $\mathrm{Na}$ syn could best be described by a sum of exponential and linear terms: $j=P\left(1-e^{-k_{1} t}\right)+k_{2} t$. The second-order rate constant, $k_{2}$, was evaluated by measuring ${ }^{45} \mathrm{Ca}$ influx in synaptosomes after the exponential phase had been abolished (inactivated) by predepolarizing synaptosomes for $5 \mathrm{sec}$. The rate of $\Delta K^{+}$-dependent $\mathrm{Ca}$ influx after inactivation of the channels was $0.17 \pm$ $0.01 \mathrm{nmol} / \mathrm{sec} / \mathrm{mg}$ protein. The least-squares fit of the data to equation $j=P\left(1-e^{-k t}\right)+0.17 t$ gave $k_{1}=1.0 \pm 0.1 \mathrm{sec}^{-1}$ and $P=3.3 \perp 0.1 \mathrm{nmol} / \mathrm{mg}$ protein for the exponential phase of $\mathrm{Ca}$ influx. Interestingly, despite the overall fit of the data to a twocomponent model of $\mathrm{Ca}$ entry in Na-syn, we noted that the earliest time points (i.e., measurements at 49.5, 110.5, and 215 $\mathrm{msec}$ ) showed a tendency to deviate from the calculated curve and were lower than the values obtained with Ch-syn. At present we have no satisfactory explanation for this observation. However, it is possible that in partially depolarized Na-syn a fraction of channels are inactivated and fewer channels are available for the opening by subsequent high- $\mathrm{K}^{+}$challenge. The resultant depression of $\mathrm{Ca}$ influx would be most evident at the early time points, when the $\mathrm{Na}^{+}$-dependent $\mathrm{Ca}$ entry makes relatively negligible contribution.

\section{Kinetics of voltage-dependent channel inactivation and reactivation}

The earlier observations that predepolarization of synaptosomes in high- $\mathrm{K}^{+}$media abolished the early phase of Ca entry (Nachshen, 1985; Nachshen and Blaustein, 1980; Suszkiw and O'Leary, 1983) suggested that voltage-dependent inactivation of 


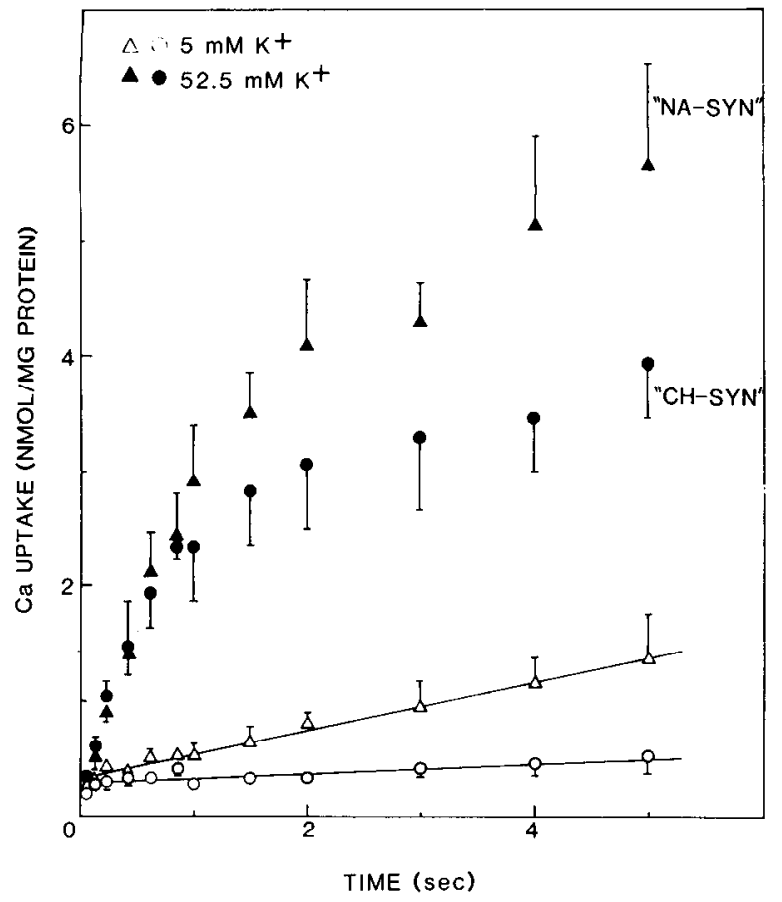

Figure 2. Time course of ${ }^{45} \mathrm{Ca}$ uptake. Uptake was measured in $\mathrm{Na}^{+}-$ loaded $(N A-S Y N)$ and $\mathrm{Na}^{+}$-deficient $(C H-S Y N)$ synaptosomes between 0.05 and $5 \mathrm{sec}$ of incubation. Data are means \pm SD of 4-9 determinations. For details of incubation conditions, see text.

$\mathrm{Ca}^{+}$channels might account for the time course of $\mathrm{Ca}$ entry into synaptosomes. To gain further insight into the relationship between channel inactivation and the decay of $\mathrm{Ca}$ influx, we have measured the decay of channel activity as a function of the duration of predepolarization in $52.5 \mathrm{mM} \mathrm{K}^{+}$, nominally Cafree media. Under these conditions, free $\mathrm{Ca}_{\mathrm{i}}$ in synaptosomes (monitored with Quin 2) was maintained at $\sim 50 \mathrm{nM}$. The time course of channel inactivation (Fig. 4, left) was fitted to the function $Q_{\text {inact }}=q_{1} e^{-k_{i l}}+q_{2}$, where $Q_{\text {inact }}$ is the fractional ${ }^{45} \mathrm{Ca}$ uptake at time $t$ of predepolarization, $q_{1}$ is the fraction of channels undergoing exponential inactivation, $k_{i}$ is the observed rate constant of this process, and $q_{2}$ is the residual fraction of $\mathrm{Ca}$ entry showing no inactivation within the time range of these measurements. A nonlinear least-squares regression of the data obtained with Na-syn yielded $q_{1}=0.91 \pm 0.01, q_{2}=0.09 \pm$ 0.01 , and $k_{i}=0.29 \pm 0.04 \mathrm{sec}^{-1}\left(t_{1 / 2} \simeq 2.4 \mathrm{sec}\right)$. These data suggest that $90 \%$ of $\Delta K^{+}$-dependent $\mathrm{Ca}$ influx in Na-syn occurs via the channels that show single-exponential inactivation kinetics. The residual $q_{2}$ fraction $(\sim 10 \%)$ is attributed to the Nadependent fraction of $\mathrm{Ca}$ entry. It may be noted that the rate of channel inactivation in $52.5 \mathrm{mM} \mathrm{K}^{+}$solutions is considerably slower than the rate at which channel-mediated $\mathrm{Ca}$ entry terminates $\left(t_{y_{2}} \sim 0.5-0.7 \mathrm{sec}\right)$.

In these experiments, inactivation was measured in synaptosomes that were initially equilibrated in standard HKR solution $(140 \mathrm{~mm} \mathrm{NaCl})$, and $\mathrm{Na}^{+}$was lowered to $92.5 \mathrm{Na}^{+}$only in the course of depolarization. We ascertained that this had no effect on the measurements in a separate series of experiments in which synaptosomes were originally suspended in media in which $\mathrm{NaCl}$ was reduced to $92.5 \mathrm{~mm}$ by isotonic substitution with $\mathrm{ChCl}$; thus, $\mathrm{Na}^{+}$concentration remained constant throughout the experiment, i.e., commencing with exchange of sucrose for the indicated medium. The data obtained with these preparations (triangles in Fig. 4) gave similar parameter estimates: $q_{1}=0.87 \pm 0.02, q_{2}=0.12 \pm 0.02$, and $k_{\text {inact }}=0.29 \pm 0.02$, indicating that transient lowering of $\left[\mathrm{Na}^{+}\right]_{0}$ had no effect on the

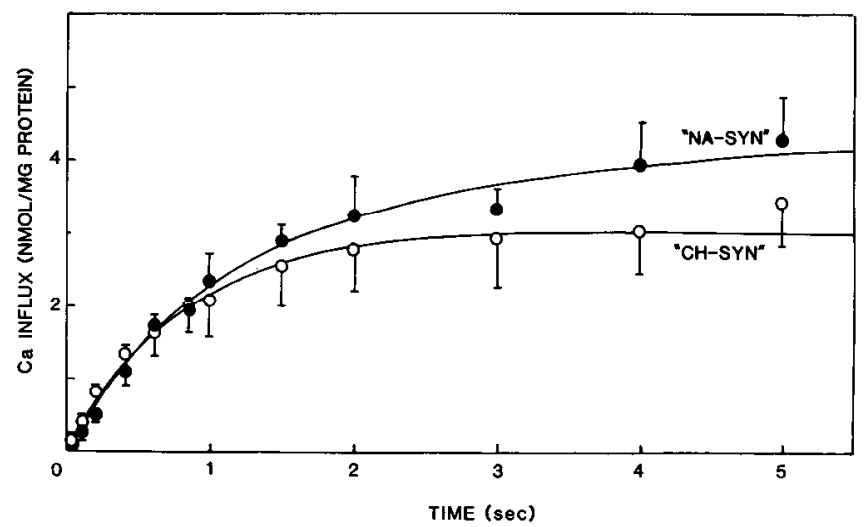

Figure 3. Time course of $\Delta \mathrm{K}^{+}$-dependent influx of Ca in NA-SYN and $\mathrm{CH}-\mathrm{SYN}$. $\Delta \mathrm{K}^{+}$-dependent influx is ${ }^{45} \mathrm{Ca}$ uptake in $52.5 \mathrm{~mm} \mathrm{~K} \mathrm{~K}^{+}$minus uptake in $5 \mathrm{~mm} \mathrm{~K} \mathrm{~K}^{+}$solutions. The regression curves obtained by the nonlinear least-squares method of data fitting describe equations $j=$ $3.0\left(1-e^{-1.3 t}\right)$ for CH-SYN and $j=3.3\left(1-\mathrm{e}^{-1.0 t}\right)+0.17 t$ for NASYN. The observed half-lives are $t_{1 / 2} \simeq 0.5 \mathrm{sec}$ and $\simeq 0.7 \mathrm{sec}$ in $\mathrm{CH}$ and NA-SYN, respectively.

measurements. Also, since presumably the internal concentration of $\mathrm{Na}^{+}$was lower in these synaptosomes, it suggests that inactivation process is not related to $\mathrm{Na}_{\mathrm{i}}{ }^{\prime}$. To exclude a possible effect of $\mathrm{Cl}^{-}$redistribution on channel activity, we replaced $\mathrm{NaCl}$ and $\mathrm{KCl}$ with the corresponding methylsulfate salts. The removal of $\mathrm{Cl}^{-}$from the external medium likewise had no significant effect on the observed decline in channel activity (data not shown).

In the next series of experiments, we measured the rate of channel recovery from inactivation after predepolarized syn-

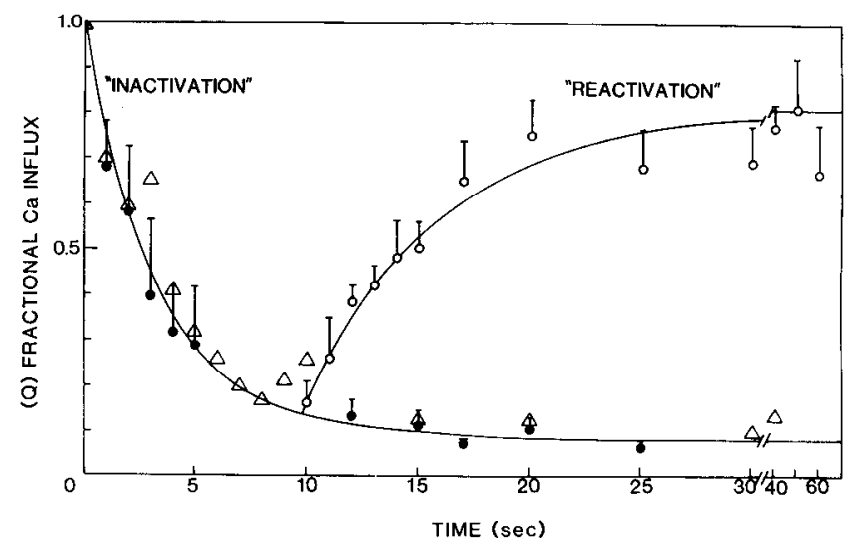

Figure 4. Time course of voltage-dependent CA channel inactivation and recovery (reactivation). Inactivation (left side) was measured in NASYN predepolarized in Ca-deficient, $52.5 \mathrm{~mm} \mathrm{~K}^{+}$media. 9 , Data obtained with synaptosomes preequilibrated in standard, $\mathrm{Na}^{+}$-rich $\mathrm{HKR}$ are means \pm SD of 3-16 determinations. $\triangle$, Data obtained with synaptosomes preequilibrated in $\mathrm{HKR}$ with reduced $\mathrm{Na}^{+}\left(92.5 \mathrm{~mm} \mathrm{Na}{ }^{+}\right.$, $47.5 \mathrm{mM} \mathrm{Ch}^{+}$) are means \pm SD of 4-8 determinations (for clarity, SD bars have been omitted). $Q$ is fractional $C$ a influx at times $t$, relative to control influx at time zero of predepolarization. The regression curve obtained by nonlinear least-squares fitting of the data describes the equation $Q_{\text {inact }}=0.91 e^{-\left(0.29 \mathrm{sec}^{-1}\right) t}+0.09$. The estimated half-life of the channel inactivation is $t_{1 / 2} \simeq 2.4 \mathrm{sec}$. Reactivation of channels (right side) was measured after returning predepolarized $\left(10 \mathrm{sec}\right.$ in $\left.52.5 \mathrm{~mm} \mathrm{~K} \mathrm{~K}^{+}\right)$ synaptosomes to nondepolarizing $5 \mathrm{~mm} \mathrm{~K} \mathrm{~K}^{+}$conditions. Data are means \pm SD of 4-8 determinations. $Q$ is fractional Ca influx relative to control at time zero of predepolarization-repolarization sequence. The regression curve obtained by the nonlinear least-squares data fitting describes equation $Q=0.18 \pm 0.63\left(1-e^{-0.16 t}\right)$. The estimated half-life of recovery is $t_{1 / 2}=4.3 \mathrm{sec}$. 


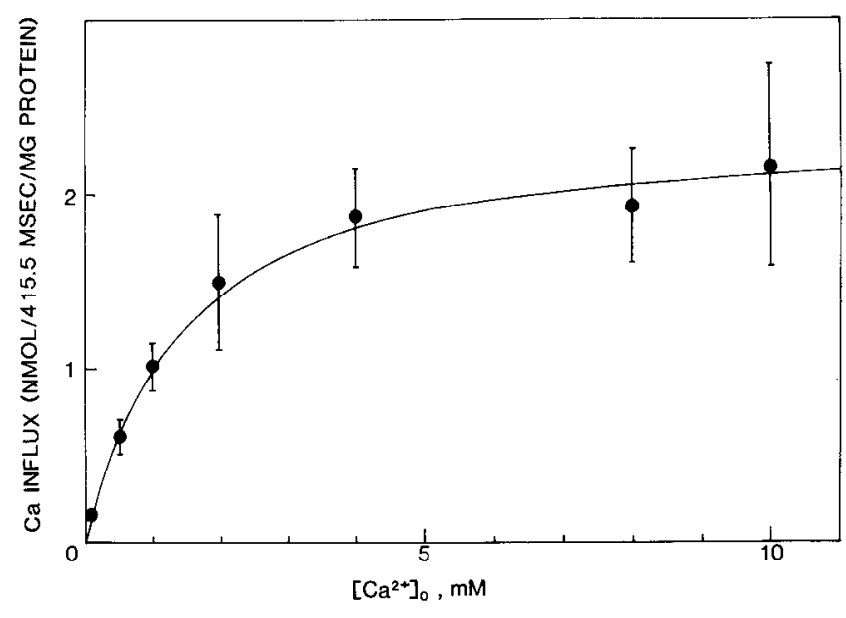

Figure 5. Initial rates of $\mathrm{Ca}$ influx as function of $\left[\mathrm{Ca}^{2+}\right]_{0}$. Data are means \pm SD of 4-7 determinations. Nonlinear least-squares fit of the data to Michaelis-Menten equation $J_{\mathrm{Ca}}=J_{\mathrm{Ca}^{\max }}\left[\mathrm{Ca}^{2+}\right]_{\mathrm{o}} /\left(K_{\mathrm{Ca}}+\left[\mathrm{Ca}^{2+}\right]_{\mathrm{o}}\right)$, gave $J_{\mathrm{Ca}}^{\max }=2.44 \pm 0.09 \mathrm{nmol} / 415.5 \mathrm{msec} / \mathrm{mg}$ protein, and $K_{\mathrm{Ca}}=$ $1.48 \pm 0.09 \mathrm{~mm}$.

aptosomes were returned to resting, $5 \mathrm{~mm} \mathrm{~K}^{+}$conditions. The time course of channel reactivation (Fig. 4 , right) was fitted to the equation $Q_{\text {rec }}=q_{0}+q_{1}\left(1-e^{-k i}\right)$, where $Q_{\text {rcc }}$ is the observed fractional channel activity at various times $t$ after return of synaptosomes to the nondepolarizing medium, $q_{0}$ is the fraction of noninactivated $\mathrm{Ca}$ entry after a $10 \mathrm{sec}$ predepolarization of synaptosomes (this parameter is essentially equivalent to $q_{2}$ in the $Q_{\text {inact }}$ equation), $q_{1}$ is the fraction of channels that recover, and $k_{\mathrm{r}}$ is the observed rate constant of recovery. Nonlinear regression of the data yielded $q_{0}=0.18 \pm 0.05, q_{1}=0.63 \pm 0.06$, and $k=0.16 \pm 0.04 \mathrm{sec}^{1}\left(l_{1 / 2} \simeq 4.3 \mathrm{sec}\right)$. The sum $q_{0}+q_{1}$ indicates that about $81 \%$ of the control uptake activity was recovered during the first minute of rest. During an additional 12 min, Ca uptake returned to nearly control values (data not shown), but there was considerable variability among preparations. A possible explanation for this variability is that a fraction of synaptosomes became functionally impaired in the course of these experiments and did not completely repolarize or did so only slowly following restoration of $5 \mathrm{mM} \mathrm{K}^{+}$conditions.

Influx of $\mathrm{Ca}$ as a function of [Ca]

The relationship between the initial rates of $\mathrm{Ca}$ influx and external concentration of $\mathrm{Ca}_{\mathrm{o}}$ (Fig. 5) was satisfactorily fitted to the Michaelis-Menten type equation:

$$
J_{\mathrm{Ca}}=\left(J_{\mathrm{Ca}}{ }^{\max }[\mathrm{Ca}]_{\mathrm{o}}\right) /\left(K_{\mathrm{Ca}}+[\mathrm{Ca}]_{\mathrm{o}}\right)
$$

where $J_{C_{a}}$ is the measured $\mathrm{Ca}$ influx at various concentrations of $\mathrm{Ca}$ in the medium, $J_{\mathrm{Ca}^{\max }}$ is the maximal rate of influx at saturating concentration of $\mathrm{Ca}^{2+}$, and $K_{\mathrm{Ca}}$ is the external concentration of $\mathrm{Ca}$ at which $J_{\mathrm{Ca}}=J_{\mathrm{Ca}^{\max } / 2}$. The initial rates of $\mathrm{Ca}$ influx in $\mathrm{Na}$-syn were measured with $\mathrm{Ca}_{0}$ concentrations ranging from 0.1 to $10 \mathrm{~mm}$. Uptake of ${ }^{45} \mathrm{Ca}$ was measured during 415.5 msec of depolarization by $52.5 \mathrm{~mm} \mathrm{~K} \mathrm{~K}^{+}$and was corrected for the basal Ca uptake in $5 \mathrm{mM} \mathrm{K}^{+}$. Nonlinear least-squares regression analysis of the data gave $J_{\mathrm{Ca}}{ }^{\max }=5.9 \pm 0.2 \mathrm{nmol} / \mathrm{sec} / \mathrm{mg}$ protein, and $K_{\mathrm{Ca}}=1.5 \pm 0.1 \mathrm{~mm}$.

The average surface-to-volume ratio estimated from electron micrographs of synaptosomes is $83 \mathrm{~cm}^{2} / \mu$ l (Marchbanks and Campbell, 1976). The synaptosomal surface area in our preparations calculated from corrected ${ }^{3} \mathrm{H}_{2} \mathrm{O}$ space of $2.7 \mu \mathrm{l} / \mathrm{mg}$ was about $2 \times 10^{10} \mu \mathrm{m}^{2} / \mathrm{mg}$ protein. Assuming that accumulation of ${ }^{45} \mathrm{Ca}$ in synaptosome during the $415 \mathrm{msec}$ incubations represents a net unidirectional flux (e.g., see Nachshen, 1985; Nachshen and Blaustein, 1980), $J_{\mathrm{Ca}}{ }^{\max }$ corresponds to the flux of 1.7 $\times 10^{\mathrm{s}} \mathrm{Ca}$ ions $/ \mathrm{sec} / \mu \mathrm{m}^{2}$ synaptolemmal surface area.

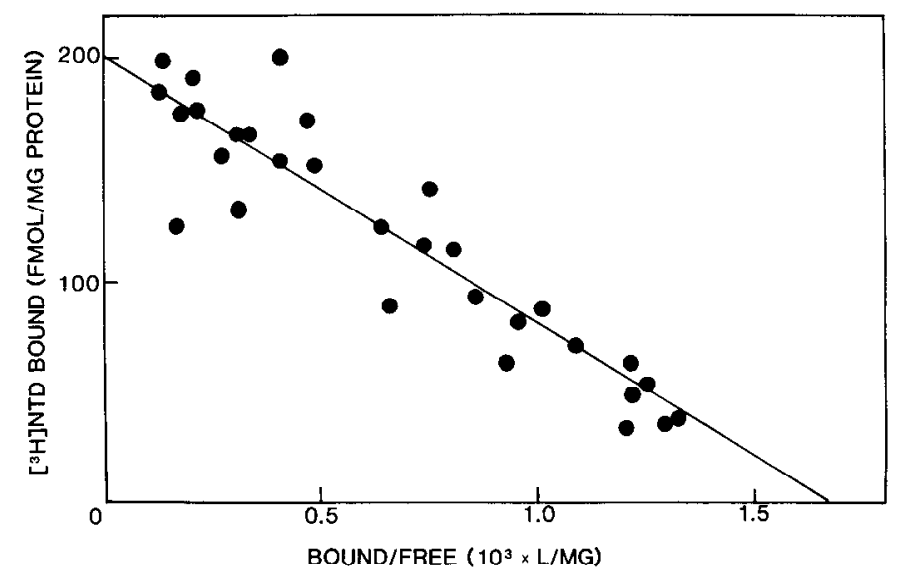

Figure 6. Scatchard plot of equilibrium binding of ${ }^{3} \mathrm{H}$-nitrendipine to synaptosomes. Experiments were done with CH-SYN in Na-deficient media, with nitrendipine concentrations in the range of $0.04-1.5 \mathrm{~nm}$. The data points have been corrected for nonspecific binding in the presence of $1 \mu \mathrm{M}$ nitrendipine and are from six preparations. The leastsquares analysis of the data gave $B_{\max }=203.5 \pm 42(\mathrm{SD}) \mathrm{fmol} / \mathrm{mg}$ protein and $K_{\mathrm{D}}=0.12 \pm 0.08 \mathrm{nM}$.

Binding of NTD to synaptosomes and effect of NTD on Ca influx The purpose of these experiments was to reexamine the relationship of NTD binding sites to Ca channels in synaptosomes. In order to avoid possible complications associated with the presence of $\mathrm{Na}^{\prime}$ (Turner and Goldin, 1985), we measured equilibrium binding of ${ }^{3} \mathrm{H}-\mathrm{NTD}$ and the effect of NTD on $\Delta \mathrm{K}^{+}$dependent ${ }^{45} \mathrm{Ca}$ influx in $\mathrm{Ch}$-syn in choline media. The equilibrium binding of ${ }^{3} \mathrm{H}-\mathrm{NTD}$ was examined between 0.03 and 1.5 nM concentration of the drug and was corrected for nonspecific binding in the presence of $1 \mu \mathrm{M}$ unlabeled NTD. The Scatchard plot of the data in Figure 6 indicates the presence of a single class of high-affinity binding sites with $B_{\max }=203.5 \pm 42 \mathrm{fmol}$ ${ }^{3} \mathrm{H}-\mathrm{NTD}$ sites $/ \mathrm{mg}$ protein and $K_{\mathrm{D}}=0.12 \pm 0.08 \mathrm{nM}$. Figure 7 shows that binding of NTD to Ch-syn in Ch-HKR was not significantly altered in the presence of $52.5 \mathrm{mM} \mathrm{K}^{+}$in the medium but was slightly depressed in $1 \mathrm{mM} \mathrm{Ca}$. A combination of high $\mathrm{K}^{+}$and $\mathrm{Ca}_{\circ}$ had no additional effect on binding of NTD to synaptosomes. Having established that conditions employed in ${ }^{45} \mathrm{Ca}$ flux measurements did not substantially decrease in NTD binding, we examined the effects of NTD on the $\mathrm{K}^{+}$-stimulated influx of $\mathrm{Ca}$ in synaptosomes preequilibrated with the drug (10 $\mu \mathrm{M}$ total added, $\sim 2.5 \mu \mathrm{M}$ free NTD) for $60 \mathrm{~min}$ under conditions used in binding experiments. As the results in Figure 8 indicate, preincubations of synaptosomes with NTD had no significant $\left(p \geq 0.2 ; t\right.$ test) effect on the $\mathrm{K}^{+}$-stimulated influx of Ca measured during $215.5 \mathrm{msec}$ depolarization with either 1 or $0.1 \mathrm{mM}$ $\mathrm{Ca}_{\mathrm{o}}$.

\section{Discussion}

The main conclusion of these experiments is that although synaptosomes comprise heterogenous populations of nerve endings, the kinetics of voltage-dependent $\mathrm{Ca}$ influx are consistent with a single compartment containing a homogenous population of voltage-dependent $\mathrm{Ca}$ channels. In several respects, our results of fast-kinetic measurements of $\mathrm{Ca}$ entry in synaptosomes are in substantial agreement with a similar study recently reported by Nachshen (1985).

\section{Time course of phasic Ca influx}

A single-exponential, rapidly decaying influx of Ca is most clearly demonstrated in Na-deficient preparations, i.e., Ch-syn. In 1 $\mathrm{mM} \mathrm{Ca}{ }_{\mathrm{o}}{ }^{2+}$, the half-time for the termination of $\Delta \mathrm{K}^{+}$-dependent $\mathrm{Ca}$ entry is $\sim 0.5 \mathrm{sec}$, and after $1-2 \mathrm{sec}$ of depolarization there is little additional ${ }^{45} \mathrm{Ca}$ accumulation in $\mathrm{K}^{+}$-depolarized syn- 


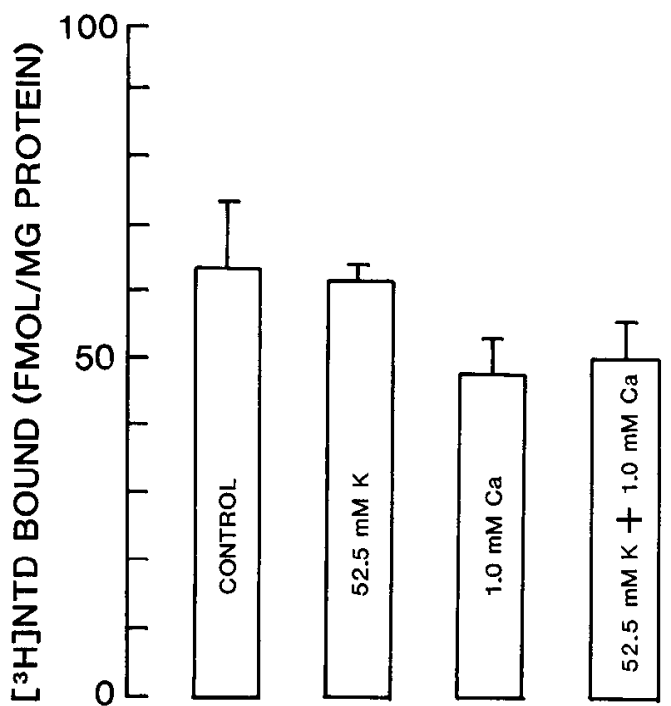

Figure 7. Effect of $52.5 \mathrm{~mm} \mathrm{~K}{ }^{+}$and $1 \mathrm{mM} \mathrm{Ca}^{2+}$ on binding of ${ }^{3} \mathrm{H}-$ nitrendipine. Binding was assayed with $0.17 \mathrm{~nm}{ }^{3} \mathrm{H}$-nitrendipine in $\mathrm{Ch}$ HKR. Control conditions were the same as in Figure 6 , i.e., $5 \mathrm{~mm} \mathrm{~K}^{+}$ and no $\mathrm{Ca}^{2+}$. Incubations were carried out for $60 \mathrm{~min}$ at $4^{\circ} \mathrm{C}$. Results are means \pm SD of three experiments.

aptosomes. In agreement with the earlier observations of Nachshen and Blaustein $(1980,1982)$, the entry of Ca into synaptosomes in $\mathrm{Na}$ media (Na-syn) can be resolved into fastexponential $\left(t_{1 / 2} \sim 0.7 \mathrm{sec}\right)$ and slow linear phases. The fastexponential $\mathrm{Ca}$ entry is consistent with passive influx of $\mathrm{Ca}$ into nerve endings through voltage-sensitive channels that inactivate in the course of depolarization (Nachshen, 1985). The presence of slow $\Delta \mathrm{K}^{+}$-stimulated, linear Ca entry component in Na-syn but not in Ch-syn, suggests a carrier-mediated, membrane-potential-sensitive (electrogenic) $\mathrm{Na} / \mathrm{Ca}$ exchange (Coutinho et al., 1984; Turner and Goldin, 1985).

\section{Kinetics of channel inactivation and recovery}

The first indication that $\mathrm{Ca}$ channels inactivate during prolonged electrical or $\mathrm{K}^{+}$depolarization was provided by Baker et al. (1973) in the squid giant axons. That channels in synaptosomes inactivate in the course of $\mathrm{K}^{+}$depolarization was first shown by Nachshen and Blaustein $(1980,1982)$ and later confirmed by us (Suszkiw and O'Leary, 1983). More recent data of Nachshen (1985) provide a further indication that the decay of Ca entry in synaptosomes may be primarily a voltage-dependent process, but the involvement of $\mathrm{Ca}$ has also been implicated by the observation that $\mathrm{Ca}$ influx decays faster at higher $\mathrm{Ca}_{0}$ concentrations. Assuming a homogenous population of $\mathrm{Ca}$ channels, inactivation should follow a simple exponential time course. In agreement with this supposition, our results show that during predepolarization of synaptosomes by $52.5 \mathrm{mM} \mathrm{K}_{\mathrm{o}}^{+}$in Ca-deficient media, $90 \%$ of channel activity decays with first-order rate constant, $k_{\mathrm{i}} \simeq 0.3 \mathrm{sec}^{-1}\left(t_{1 / 2} \sim 2.4 \mathrm{sec}\right)$. The rate of voltagedependent channel inactivation in our preparations is similar to the estimated half-time, $1-2 \mathrm{sec}$, for inactivation of channels in synaptosomes depolarized by $77 \mathrm{mM} \mathrm{K}_{\mathrm{o}}{ }^{+}$in Nachshen's (1985) experiments. The somewhat faster rate of inactivation in $77 \mathrm{~mm}$ $\mathrm{K}_{\mathrm{o}}{ }^{+}$is consistent with the dependence of the rate of channel inactivation on the level of membrane depolarization (Nachshen, 1985; M. E. O'Leary and J. B. Suszkiw, unpublished observations).

The recovery of channels from inactivation is likewise a single-exponential process, with a half-life, $t_{y_{2}}=4.3 \mathrm{sec}$, although it should be pointed out that the actual rate of channel recovery could, in fact, be somewhat faster than indicated, since we cannot be sure that our measurements are not attenuated by the

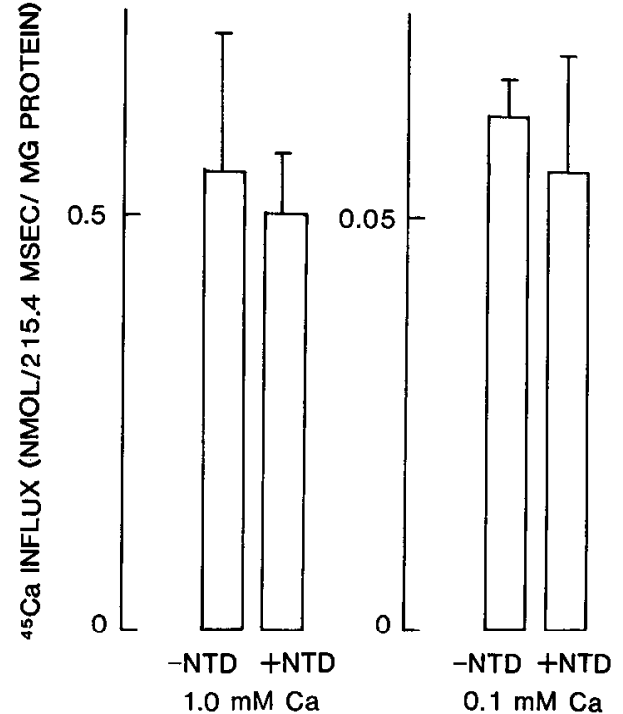

Figure 8. Effect of nitrendipine on initial rate of $\Delta \mathrm{K}^{+}$-dependent ${ }^{45} \mathrm{Ca}$ influx in CH-SYN. Synaptosomes were preequilibrated with $10 \mu \mathrm{M}(2.5$ $\mu \mathrm{M}$ free) nitrendipine for $60 \mathrm{~min}$ at $4^{\circ} \mathrm{C}$. After prewarming synaptosomes to $30^{\circ} \mathrm{C}$, influx of ${ }^{45} \mathrm{Ca}$ was assayed at $215.5 \mathrm{msec}$ with 1.0 and $0.1 \mathrm{~mm}$ $\mathrm{Ca}_{0}$. The results are means $\pm \mathrm{SD}$ of three experiments, each performed in duplicate.

rate at which synaptosomes repolarize on their return to $5 \mathrm{~mm}$ $\mathrm{K}^{+}$media. Similar rates of channel inactivation and reactivation might be expected in the case of a purely voltage-dependent process.

Comparison of the half-times for the decay of Ca influx $\left(t_{1 / 2} \simeq\right.$ $0.5-0.7 \mathrm{sec})$ and voltage-dependent channel inactivation $\left(t_{1 / 2} \simeq\right.$ $2.4 \mathrm{sec}$ ) indicates that the latter process is too slow to account for the more rapid decline of $\mathrm{Ca}$ entry into synaptosomes. At present it cannot be ruled out that the rapid decay of $\mathrm{Ca}$ entry may reflect a combination of factors associated with an increase in $\mathrm{Ca}_{\mathrm{i}}$, namely, a decrease in electrochemical driving force, increased $\mathrm{Ca}$ efflux, and, possibly, direct block of $\mathrm{Ca}$ channels by $\mathrm{Ca}_{\mathrm{i}}$. An alternative explanation may be that $\mathrm{Ca}$ entry either facilitates the voltage-dependent channel inactivation or promotes a distinct $\mathrm{Ca}_{\mathrm{i}}$-dependent inactivation process. Evidence for dual voltage and $\mathrm{Ca}_{\mathrm{i}}$-dependent channel inactivation has been obtained in snail neurons (Brown et al., 1981) and has also been implicated in cardiac tissue (Tsien, 1983). A Ca $a_{i}$-facilitated channel inactivation $(\tau=1.5 \mathrm{sec})$ has been demonstrated recently in the voltage-clamped $(0 \mathrm{mV})$ giant axon terminals in the squid (Augustine and Eckert, 1984). Interestingly, the recovery from $\mathrm{Ca}_{\mathrm{i}}$-dependent inactivation in the squid $(\tau=70$ $\mathrm{sec}$ ) is much slower than in synaptosomes. Preliminary results suggest that recovery of synaptosomal Ca channels from inactivation induced by depolarization of synaptosomes in medium containing $1 \mathrm{~mm} \mathrm{Ca}$ is also much slower $\left(t_{1 / 2} \sim 1 \mathrm{~min}\right)$ than the recovery from purely voltage-dependent inactivation. The functional state of cardiac $\mathrm{Ca}$ channels is regulated by cAMP-dependent phosphorylation (Reuter, 1983; Sperelakis, 1984). Evidence indicating that cAMP and ATP slows, and $\mathrm{Ca}_{\mathrm{i}}$ promotes, channel inactivation has been obtained in perfused snail ncurons (Dorochenko et al., 1982) and in the rat dorsal root neurons (Fedulova et al., 1981). It is thus an interesting possibility that the presynaptic $\mathrm{Ca}$ channels may be similarly modulated by phospho-dephosphorylation. An increase in $\mathrm{Ca}_{\mathrm{i}}$ might stimulate channel dephosphorylation, possibly by stimulating $\mathrm{Ca}$-regulated phosphatase activity. The rate of channel recovery would then reflect a slower rephosphorylation of channels by a cAMPdependent mechanism. This hypothesis is presently being tested in synaptosomes. 
Steady-state kinetic parameters of Ca influx: estimation of functional channel density in synaptosomes

The relation between unidirectional $\mathrm{Ca}$ influx (initial rates of $\mathrm{Ca}$ influx measured during $415 \mathrm{msec} \mathrm{K}^{+}$depolarization) and $\mathrm{Ca}_{\mathrm{o}}$ fits the Michaelis-Menten type of equation and is consistent with the notion of a homogenous population of saturable $\mathrm{Ca}$ channels. In $52.5 \mathrm{~mm} \mathrm{~K}^{+}(\Delta K=47.5 \mathrm{~mm})$, the apparent halfsaturation $\left(K_{\mathrm{Ca}}\right)$ occurs at $1.5 \mathrm{~mm} \mathrm{Ca}$, i.e., the physiological range of $\mathrm{Ca}_{0}$ concentration. $J_{\mathrm{Ca}}{ }^{\max }$, the limiting value of Ca influx at saturation is $5.9 \mathrm{nmol} / \mathrm{sec} / \mathrm{mg}$ protein and corresponds to the flux of $\sim 1.7 \times 10^{5} \mathrm{Ca}^{2+}$ ions $/ \mathrm{sec} / \mu \mathrm{m}^{2}$ or a current of $\sim 0.06 \mathrm{pA} /$ $\mu \mathrm{m}^{2}$ of synaptolemmal surface area.

The macroscopic $\mathrm{Ca}$ flux or current can be expressed as a product of the number of functional channels $\left(N_{f}\right)$, single-channel current $(j)$, and the probability of channel opening $(p)$ (Tsien, 1983):

$$
J^{\max }=N_{f} j p .
$$

Based on our estimates of intrasynaptosomal $\mathrm{Na}^{+}$and $\mathrm{K}^{+}$concentrations, the membrane potential in synaptosomes depolarized by $52.5 \mathrm{~mm} \mathrm{~K}_{\mathrm{o}}{ }^{+}$may be in the range -20 to $\pm 10 \mathrm{mV}$. At this level of membrane depolarization, and at saturating concentrations of $\mathrm{Ca}_{0}$, single-channel currents estimated in snail neurons (Krishtal et al., 1981) and chromaffin cells (Fenwick et al., 1982) are about $0.1 \mathrm{pA}$. Assuming this value for Ca channels in synaptosomes, the minimum number (assumption of $p=1$ ) of functional Ca channels in synaptosomes would be $0.6 \mu \mathrm{m}^{-2}$. The probability of channel opening in $\mathrm{K}^{+}$-stimulated synaptosomes could be as low as 0.1 . Thus, the number of functional $\mathrm{Ca}$ channels in synaptosomes may be $0.6-6 \mu \mathrm{m}^{-2}$. This may be compared with channel density of $1 \mu \mathrm{m}^{-2}$ in rat clonal pituitary cells (Hagiwara and Ohmori, 1982), 5-15 $\mu \mathrm{m}^{-2}$ in chromaffin cells (Fenwick et al., 1982), and 30-60 $\mu \mathrm{m}^{-2}$ in snail neurons (Krishtal et al., 1981). However, it should be noted that the estimated density of "functional" channels ignores the possibility that a substantial fraction of channels in synaptosomes may be in inactivated form and unavailable for opening.

\section{Relation of NTD receptors to Ca channels}

There are indications of several classes of neuronal Ca channels that differ in their sensitivity to Ca antagonists (Miller, 1985). In the chick dorsal ganglion neurons, three distinct types of $\mathrm{Ca}$ channels have been identified, but only one (the L-channel) is responsive to Ca channel agonist Bay K 8644 (Nowycky et al., 1985).

The presence of the high-affinity $\left(K_{\mathrm{D}} \sim 0.12 \mathrm{nM}\right){ }^{3} \mathrm{H}-\mathrm{NTD}$ binding sites, but with a negligible effect of $>10^{4} \times K_{\mathrm{D}}$ concentrations of the drug on the $\mathrm{K}^{+}$-stimulated, channel-mediated $\mathrm{Ca}$ influx in our preparations of synaptosomes, suggests a dihydropyridine-insensitive type of $\mathrm{Ca}$ channels in nerve endings. This observation agrees with several previous reports (Daniell et al., 1983; Miller and Friedman, 1984; Nachshen and Blaustein, 1979; Rampe et al., 1984) but differs from the results of Turner and Goldin (1985), who demonstrated that $1 \mu \mathrm{M}$ NTD inhibited $\mathrm{Ca}$ entry in their synaptosome preparations by about $30-40 \%$.

One criticism (Turner and Goldin, 1985) of the earlier studies is that $\mathrm{Ca}$ uptake was measured during relatively long (e.g., 10 sec) incubation times. Since rapid inactivation of the channels appears to be related to changes in $\mathrm{Ca}_{i}$, it is conceivable that a depression of $\mathrm{Ca}$ influx by a channel antagonist might slow the rate of channel inactivation. In the course of long $(>1 \mathrm{sec})$ incubations, this might lead to a spurious result of a similar $\mathrm{Ca}$ accumulation in control and drug-treated preparations. Since in the present work we measured the initial rates of $\mathrm{Ca}$ influx during very short $(215 \mathrm{msec})$ depolarization and tested the effect of the drug in normal, $1 \mathrm{~mm}$, and reduced, $0.1 \mathrm{~mm}, \mathrm{Ca}_{0}$, this possibility can be excluded. The failure to detect functional, dihydropyridine-sensitive $\mathrm{Ca}$ channels in the Gray and Whittaker (1962) preparation employed by us but apparently not in the Hajos (1975) preparation used by Turner and Goldin could be due to differences in the metabolic states of nerve endings in the two preparations. It has been suggested that the high-affinity binding sites for dihydropyridine $\mathrm{Ca}$ antagonists may reflect an inactive state of the Ca channels (Bean, 1984). Also, the results of Nowycky et al. (1985) indicate that the dihydropyridine-sensitive channels are more labile than the dihydropyridine-insensitive channels. With the foregoing considerations in mind, the discrepancy between our results and those of Turner and Goldin could be accounted for by assuming that the high-affinity ${ }^{3} \mathrm{H}$ NTD sites in our preparations correspond to a distinct class of inactivated, dihydropyridine-sensitive channels. Interestingly, the density of these putative channels, estimated from the $B_{\max } \simeq 200 \mathrm{fmol} \mathrm{NTD} / \mathrm{mg}$ protein and the surface area $2 \times 10^{10}$ $\mu \mathrm{m}^{2} / \mathrm{mg}$ protein, would be about $6 \mu \mathrm{m}^{-2}$, i.e., similar to the estimated density, 0.6-6 $\mu \mathrm{m}^{-2}$, of functional NTD-insensitive channels.

An alternative explanation for the apparent insensitivity of synaptosomal Ca channels to NTD may be that in our preparations the functional channels and/or the dihydropyridine receptors are in a conformation with a very low affinity for $\mathrm{Ca}$ antagonists (Bean, 1984; Nachshen, 1985). Finally, it cannot be completely ruled out that the NTD sites are, in fact, unrelated to $\mathrm{Ca}$ channels in nerve endings but rather are associated with the contaminating membranes. This would seem inconsistent with the inhibition by dihydropyridines of ${ }^{3} \mathrm{H}$-norepinephrine release reported by Turner and Goldin (1985). However, it may be noted that release of transmitters may also occur from dendrites, and there are indications that dendrites may contain the dihydropyridine-responsive type of Ca channels (Miller, 1985). Thus, it is conceivable that the presence of metabolically competent "dendrosomes" in Turner and Goldin's preparations but not in ours might be the source of the observed discrepancies between our results and theirs. Further studies comparing the channels and their responsiveness to dihydropyridines in the two types of synaptosome preparations may help to clarify some of these issues.

\section{References}

Ashley, R. H., M. J. Brammer, and R. Marchbanks (1984) Measurement of intrasynaptosomal free calcium by using the fluorescent indicator quin-2. Biochem. J. 219: 149-158.

Augustine, G. J., and R. Eckert (1984) Calcium-dependent inactivation of presynaptic calcium channels. Soc. Neurosci. Abstr. 9: 194.

Baker, P. F., H. Meves, and E. B. Ridgway (1973) Calcium entry in response to maintained depolarization of squid axons. J. Physiol. (Lond.) 231: 527-548.

Bean, B. P. (1984) Nitrendipine block of cardiac calcium channels: High affinity binding to the inactivated state. Proc. Natl. Acad. Sci. USA 81: 6388-6392.

Blaustein, M. P., and J. M. Goldring (1975) Membrane potentials in pinched-off presynaptic nerve terminals, monitored with a fluorescent probe: Evidence that synaptosomes have potassium diffusion potentials. J. Physiol. (Lond.) 247: 589-615.

Blaustein, M. P., and C. J. Oborn (1975) The influence of sodium on calcium fluxes in pinched-off nerve terminals in vitro. J. Physiol. (Lond.) 247: 657-686.

Brown, A. M., K. Morimoto, Y. Tsuda, and D. L. Wilson (1981) Calcium current-dependent and voltage-dependent inactivation of calcium channels in Helix Aspersa. J. Physiol. (Lond.) 320: 193-218.

Campbell, C. W. P. (1976) The $\mathrm{Na}^{+}, \mathrm{K}^{+}, \mathrm{Cl}^{-}$contents and derived membrane potentials of presynaptic nerve endings in vitro. Brain Res. 101: 594-599.

Carafoli, E., and M. Crompton (1978) The regulation of intracellular calcium by mitochondria. Ann. NY Acad. Sci. 307: 269-284.

Coutinho, O. P., C. A. M. Carvalho, and A. Carvalho (1984) Calcium 
uptake related to $\mathrm{K}^{+}$-depolarization and $\mathrm{Na}^{+} / \mathrm{Ca}^{+}$exchange in sheep brain synaptosomes. Brain Res. 290: 261-271.

Daniell, L. C., E. M. Barr, and S. W. Leslie $(1983){ }^{45} \mathrm{Ca}^{2+}$ uptake into rat whole brain synaptosomes unaltered by dihydropyridine calcium antagonists. J. Neurochem. 41: 1455-1459.

Dorochenko, P. A., P. G. Kostyuk, and A. E. Martynyuk (1982) Intracellular metabolism of adenosine $3^{\prime}, 5^{\prime}$-cyclic monophosphate and calcium inward current in perfused neurons of helix pomatia. Neuroscience $7: 2125-2134$.

Drapeau, P., and M. P. Blaustein (1983) Initial release of $\left[{ }^{3} \mathrm{H}\right]$ dopamine from rat striatal synaptosomes: Correlation with calcium entry. J. Neurosci. 3: 703-713.

Fedulova, S. A., P. G. Kostyuk, and N. S. Vesolovsky (1981) Calcium channels in the somatic membrane of the dorsal root ganglion neurons, effect of cAMP. Brain Res. 214: 210-214.

Fenwick, E. M., A. Marty, and E. Neher (1982) Sodium and calcium channels in bovine chromaffin cells. J. Physiol. (Lond.) 331: 599635.

Froehlich, J. P., J. V. Sullivan, and R. L. Berger (1976) A chemical quenching apparatus for studying rapid reactions. Anal. Biochem. 73: 331-341.

Gray, E. G., and V.P. Whittaker (1962) The isolation of nerve endings from brain: An electron microscopic study of cell fragments derived by homogenization and centrifugation. J. Anat. 96: 79-88.

Hagiwara, S., and L. Byerly (1981) Calcium channel. Annu. Rev. Neurosci. 4: 69-125

Hagiwara, S., and H. Ohmori (1982) Studies of calcium channels in rat clonal pituitary cells with patch electrode voltage clamp. J. Physiol. (Lond.) 331: 231-252.

Hajos, F. (1975) An improved method for the preparation of synaptosomal fractions in high purity. Brain Res. 93: 485-489.

Jennrich, R. (1983) Nonlinear regression. In BMDP Statistical Software, W. J. Dixon, ed., pp. 290-304, University of California Press, Berkeley.

Katz, B. (1969) The Release of Neural Transmitter Substances, Thomas, Springfield, IL.

Keen, P., and T. D. White (1971) The permeability of pinched-off nerve endings to sodium, potassium and chloride and the effects of gramicidin. J. Neurochem. 18: 1097-1103.

Kostyuk, P. G. (1981) Calcium channels in neuronal membrane. Biochim. Biophys. Acta 650: 128-150.

Krishtal, O. H., V. I. Podoplichko, and Y. A. Shakhovolov (1981) Conductance of the calcium channel in the membrane of snail neurons. J. Physiol. (Lond.) 310: 423-434.

Llinás, R., and J. R. Heuser (1977) Depolarization-release coupling systems in neurons. Neurosci. Res. Prog. Bull. 276: 557-687.

Lowry, O. H., N. J. Rosebrough, A. L. Farr, and R. J. Randall (1951) Protein measurement with the folin phenol reagent. J. Biol. Chem. 193: 265-275.

Marchbanks, R. M., and C. W. B. Campbell (1976) Sodium and chloride fluxes in synaptosomes in vitro. J. Neurochem. 26: 973-980.

Miller, R. J. (1985) How many types of calcium channels exist in neurons? TINS 8 : 45-47.

Miller, R. J., and S. B. Friedman (1984) Are dihydropyridine binding sites voltage sensitive calcium channels? Life Sci. 34: 1205-1221.
Mullins, L. J. (1976) Steady-state calcium fluxes: Membrane versus mitochondrial control of ionized calcium in axoplasm. Fed. Proc. 35 . 2583-2588.

Nachshen, D. A. (1985) The early time-course of potassium-stimulated calcium uptake in presynaptic nerve terminals isolated from rat brain. J. Physiol. (Lond.) 361: 251-268.

Nachshen, D. A., and M. P. Blaustein (1979) The effects of some organic "calcium antagonists" on calcium influx in presynaptic nerve terminals. Mol. Pharmacol. 16: 579-586.

Nachshen, D. A., and M. P. Blaustein (1980) Some properties of potassium-stimulated calcium influx in presynaptic nerve endings. $J$. Gen. Physiol. 76: 709-728.

Nachshen, D. A., and M. P. Blaustein (1982) Influx of calcium, strontium, and barium in presynaptic nerve endings. J. Gen. Physiol. 79. 1065-1087.

Nowycky, M. C., A. P. Fox, and R. W. Tsien (1985) Three types of neuronal calcium channel with different calcium agonist sensitivity. Nature 316: 440-443.

O'Leary, M. E., and J. B. Suszkiw (1985) Inactivation and reactivation of Ca-channels in synaptosomes. American Society of Neurochemistry Meeting, Abstr. 392, p. 289.

Rampe, D., R. A. Janis, and D. J. Triggle (1984) Bay K 8644, a 1,4dihydropyridine $\mathrm{Ca}^{2+}$ channel activator: Dissociation of binding and functional effects in brain synaptosomes. J. Neurochem. 43: 16881691.

Reuter, H. (1983) Calcium channels modulation by neurotransmitters, enzymes and drugs. Nature 301: 569-574.

Richards, C. D., J. C. Metcalfe, and T. R. Hesketh (1984) Changes in free calcium levels and $\mathrm{pH}$ in synaptosomes during transmitter release. Biochim. Biophys. Acta 803: 215-220.

Sperelakis, N. (1984) Hormonal and neurotransmitter regulation of $\mathrm{Ca}^{++}$influx through voltage-dependent slow channels in cardiac muscle membrane. Membr. Biochem. 5: 131-165.

Suszkiw, J. B., and M. E. O'Leary (1983) Temporal characteristics of potassium-stimulated acetylcholine release and inactivation of calcium influx in rat brain synaptosomes. J. Neurochem. 41:868-873.

Tsien, R. W. (1983) Calcium channels in excitable membranes. Annu. Rev. Physiol. 45: 341-358.

Tsien, R. W., T. Pozzan, and T. J. Rink (1982) Calcium homeostasis in intact lymphocytes: Cytoplasmic free calcium monitored with a new, intracellularly trapped fluorescent indicator. J. Cell Biol. 94. 325-334.

Turner, T. J., and S. M. Goldin (1985) Calcium channels in rat brain synaptosomes: Identification and pharmacological characterization. High affinity blockade by organic $\mathrm{Ca}^{2+}$ channel blockers. J. Neurosci. 5: 841-849.

Wang, T., M. M. Murawsky, and J. B. Suszkiw (1985) Fast-kinctic characterization of voltage-dependent $\mathrm{Ca}^{2+}$ entry in synaptosomes. Biophys. J. 47: 433a.

Yamamura, H. L., H. Schoemaker, R. G. Boles, and W. R. Roeske (1982) Diltiazem enhancement of $\left[{ }^{3} \mathrm{H}\right]$ nitrendipine binding to calcium channel associated drug receptor sites in rat brain synaptosomes. Biochem. Biophys. Res. Commun. 108: 640-646. 